\title{
Assessment of Floral Organs State of Tilia Genus Representatives under Environment Pollution Conditions caused by Emissions of Prydniprovska Thermal Power Plant, Dnipropetrovsk city
}

\author{
Zoya Grytsay ${ }^{1 a}$ and Galyna Miasoid ${ }^{2}$ *
}

\author{
${ }^{1}$ Associate Professor, the Department of Plant Physiology and Introduction, \\ Oles' Honchar Dnipropetrovsk National University, 24, Kazakova str., Building 17, Ukraine - 49000 \\ ${ }^{2}$ Associate Professor, The Department of International Tourism and Language Training, \\ Alfred Nobel University, 18, Sicheslavska Naberezhna str., Dnipropetrovsk, Ukraine - 49000 \\ a E-mail address: gritsaj.zoja@yandex.ru \\ *Corresponding Email: galyna.miasoid@gmail.com
}

Keywords: technogenic pollution, woody plants, bloom intensity, pollen fertility

\begin{abstract}
The effect of polluting the environment with the emissions of the Prydniprovska Thermal Power Plant emissions, Dnipropetrovsk city, on morphometric and cytogenetic indicators of floral system of Tilia genus representatives was examined. The research was conducted in June and July in 2015. The studied objects in conditions of technogenesis show reduction of the bloom intensity rate and an increase of pollen grain sterility, which is the most significant in T. cordata. Sensitive indicators of Tilia generative sphere were suggested as informative test parameters for the use in monitoring the environment state. The recommendations are offered on the use of species of the Tilia genus in gardening industrial sites in terms of the steppe Prydniprovya.
\end{abstract}

\section{Introduction}

Dnipropetrovsk is one of the largest industrial centers of Ukraine. Prydniprovska Thermal Power Plant (TPP) emits the biggest number of harmful substances in the air of the city in comparison with other enterprises within its borders [1].

Tree plantation is a powerful filter used for purifying the air, water and soil from man-made pollutants. They successfully absorb significant number of chemical compounds coming from industrial, energy, transport and other types of emissions. [2-4]. Therefore, the creation of green areas using trees plays a significant role in optimizing the urban environment with high levels of man-made pollution [5, 6]. It is worth considering, that the plants, carrying out the clearing function, are exposed to the negative impact of harmful substances, resulting in the inhibition process of their growth and development [2, 7-14]. Therefore, when range of species for landscaping industrialized cities is selected, it is necessary to consider the ability of plants to absorb harmful compounds, maintain their aesthetic quality in terms of environmental pollution, as well as their tolerance to anthropogenic emissions $[6,15,16]$.

Stability of natural and artificial plant communities depends largely on their ability to maintain the proper level of seed recovery. This is essential as seed propagation of woody plants plays a key role in maintaining the genetic flexibility and resistance of most species in forest communities [12, $17,18$.$] Bloom is an important stage in the reproductive phase of plant ontogenesis, which has a$ major influence on the success of pollination and fertilization processes, and respectively the level of seed crop. Therefore, the examination of plant floral organs in areas of technogenesis is of significant interest.

The species of Tilia genus are an important part of the system of green building. High ornamental properties of Tilia trees make them attractive for greening the urban areas. However, the widespread use of green space, involving Tilia trees, its organizing and farming requires deep knowledge of their botanical, biological and environmental features. In particular, it is important to consider the species resistance in specific environmental conditions $[6,16]$. The previous research was devoted to the study of some growth indicators Tilia representatives in conditions of an 
industrial city in the southeast of Ukraine. There is evidence of the impact of emissions from motor vehicles on the assimilation system of Tilia genus [19, 20], its seed productivity [21], the parameters of anatomical stem structure under conditions of polluting the environment with emissions of the TPP [22], the state of the reproductive organs under the complex contamination with the emissions of metallurgical industry and petrol fumes [6]. However, there is little research in the generative system sensitivity of different species of Tilia genus to TPP emissions in terms of the steppe Prydniprovya.

In this study, we present the results of the part of our research on tolerance of Tilia genus representatives in the south-east area of Ukraine contaminated with the emissions of Prydniprovska TPP, Dnipropetrovsk city. Our previous research made it possible to examine and analyze the histological parameters of Tilia stem affected by the emissions of the same technogenic object [22], while the present paper aims at assessing the impact of pollution emissions of the TPP on cytogenetic and morphometric parameters of the floral system of woody plants of Tilia genus. The research was done in June and July in 2015.

\section{Materials and Methods}

The research objects are Tilia platyphyllos Scop., T. europaea L., T. cordata Mill. The samples were taken in June and July in 2015 at the two monitoring zones: the test area, formed by tree plantation adjacent to the Prydniprovska TPP, Dnipropetrovsk, in which emissions of major pollutants such as sulfur dioxide, nitrogen oxides and solid impurities make $67.3 \%, 18.7 \%$, and $13.3 \%$ respectively in the total emissions volume [1]; and the relatively clean reference area, which is the Botanical Garden of Dnipropetrovsk National University named after O.Honchar, where according to the data provided by the Sanitary \& Epidemiological Service the urban concentrations of pollutants do not exceed the MCL.

In the both sites the inflorescence were collected from several model trees, from branches of the same branching order from the south-east side of the crown. The study of morphometric parameters of flowering was conducted using the conventional methods. Pollen fertility was evaluated by iodine method suggested by Z.Pausheva [23]. For this purpose the mature anther sacs were removed from buds, then moistened with iodine solution on the microscope slide and temporary squash preparations were made. They were then viewed under Bresser Biolux microscope at a magnification of 160 times. The pollen grains were considered fertile if they had granular cytoplasm and were completely painted by reaction of iodine with starch. On the contrary, pollen grains were viewed as sterile if they were either partly painted or completely unpainted. For each species we examined 50 random field of view in every of the test areas. The solution saturation was high. The dimensions of pollen grains were measured with a micrometer eyepiece at a magnification of 640 times.

The experimental results are statistically processed. An average arithmetic error was calculated. To compare the reference and test samples the Student's t-test $(\mathrm{p}<0.05)$ was applied. Normality allocation of the sample had been preliminary assessed. Sample size for each of the examined parameters was 50 samples $(n=50)$.

\section{Results and Discussions}

In the examined representatives of Tilia genus, which have been growing in plant communities, that suffer chronic exposure to emissions of thermal power plants, the bloom intensity indicators show a downward trend. As shown in Table. 1, the number of buds on a model branch in a tree in the test area has reduced compared with the reference area results. Under the influence of man-made emissions this parameter goes down the most significantly in T. platyphyllos representatives $(18.0 \%$ compared to reference trees), and to a lesser extent - in T. europaea and T. cordata ( $9.8 \%$ and $15.7 \%$ respectively). The number of flowers in the inflorescence in all the research objects in the industrial area plummeted compared with the reference zone. However, T. cordata proves to be the most vulnerable to pollution (see Table. 1). 
As a result of inflorescences determination inhibition and the subsequent merome determination, resulting in the reduced number of buds on a model branch and the number of flowers in them, the trees demonstrated the reduction of bloom intensity in technologically the contaminated zone, which was defined as the total number of flowers per branch model. Among the studied objects the influence of this parameter emissions of Prydniprovska TPP decreases dramatically in $T$. cordata (28.4\% compared to control) and is less significant in T. europaea and T. platyphyllos $(18.7 \%$ and $252 \%$, respectively) (see Table. 1)

Table 1. The influence of Prydniprovska TPP emissions, Dnipropetrovsk city, on bloom intensity of Tilia genus representatives $(\mathrm{n}=50)$

\begin{tabular}{|c|c|c|c|}
\hline Species & Reference area & Test area & Control ratio, $\%$ \\
\hline \multicolumn{4}{|c|}{ Inflorescence number in a model branch [units] } \\
\hline T. platyphyllos & $27.2 \pm 0.41$ & $22.3 \pm 0.36$ & 82.0 \\
\hline T. europaea & $25.4 \pm 0.34$ & $22.9 \pm 0.29$ & 90.2 \\
\hline T. cordata & $48.5 \pm 0.58$ & $40.9 \pm 0.64$ & 84.3 \\
\hline \multicolumn{4}{|c|}{ Flower number in a inflorescence [units] } \\
\hline T. platyphyllos & $3.85 \pm 0.08$ & $3.32 \pm 0.06$ & 86.2 \\
\hline T. europaea & $5.24 \pm 0.11$ & $4.39 \pm 0.14$ & 83.8 \\
\hline T. cordata & $8.02 \pm 0.26$ & $6.36 \pm 0.17$ & 79.3 \\
\hline \multicolumn{4}{|c|}{ Flower number in a model branch [units] } \\
\hline T. platyphyllos & $109.2 \pm 3.06$ & $81.7 \pm 2.40$ & 74.8 \\
\hline T. europaea & $128.6 \pm 3.12$ & $104.5 \pm 3.07$ & 81.3 \\
\hline T. cordata & $363.5 \pm 9.14$ & $260.3 \pm 6.83$ & 71.6 \\
\hline
\end{tabular}

The plant floral organs research in the areas of technogenic it is essential to measure the pollen fertility, because it determines the success of pollination and fertilization processes. The data on the level of pollen grain sterility is also an important source of information for monitoring the environment due to the high sensitivity of the male generative system of plants to adverse factors [24-26.] The obtained results indicate that fertility of pollen grains in the trees that were subjected to chronic exposure to emissions of Prydniprovska TPP is lower than in the plants in the reference area. It should be noted that the species studied for this indicator show different sensitivity to anthropogenic emissions. T. cordata shows the most significant fall of pollen fertility rate in terms of pollution (98, 3\% in the reference area $v s 76.9 \%$ in the test area), and it decreases to a lesser extent in T. platyphyllos (from $93.6 \%$ to $88.0 \%$ respectively) (see Table. 2.)

Table 2. The influence of Prydniprovska TPP emissions, Dnipropetrovsk city, on pollen fertility and pollen grain size of Tilia genus representatives $(\mathrm{n}=50)$

\begin{tabular}{|l|c|c|c|}
\hline \multicolumn{1}{|c|}{ Species } & Reference area & Test area & Control ratio, \% \\
\hline \multicolumn{4}{|c|}{ Pollen fertility [\%] } \\
\hline T. platyphyllos & $93.6 \pm 0.86$ & $88.0 \pm 0.72$ & 94.0 \\
\hline T. europaea & $96.6 \pm 0.91$ & $94.1 \pm 0.89^{*}$ & 97.4 \\
\hline T. cordata & $98.3 \pm 1.04$ & $76.9 \pm 0.90$ & 78.2 \\
\hline \multicolumn{4}{|c|}{ Pollen grain diameter [ $\mu \mathrm{m}]$} \\
\hline T. platyphyllos & $36.2 \pm 0.32$ & $35.8 \pm 0.28^{*}$ & 98.9 \\
\hline T. europaea & $35.4 \pm 0.29$ & $34.6 \pm 0.25^{*}$ & 97.7 \\
\hline T. cordata & $31.0 \pm 0.21$ & $29.6 \pm 0.16$ & 95.4 \\
\hline
\end{tabular}

* - differ significantly from control $(\mathrm{p}<0.05)$

For T. europaea the difference of this parameter in trees in the test and reference zones is statistically insignificant at $\mathrm{P}<0.05$ (see Table. 2). Other researchers also noted the rise of pollen sterility under conditions of anthropogenic impact $[6,24]$. 
Having compared the data on the size of pollen grains in Tilia representatives in the industrial and the reference areas, we have found that this index shows the greatest stability in the industrial environment in the research objects. Thus, the length of pollen grains under the influence of the Prydniprovska TPP emissions reduces insignificantly in comparison with the reference data only in T. cordata (by 4.7\%). The difference between these indices in the reference and test plots for the other two species (T. platyphyllos and T. europaea) is statistically insignificant (see Table. 2).

\section{Conclusions}

The research data reveal inhibition of the flower evocation and floral morphogenesis under chronic exposure to Prydniprovska TPP emissions in Tilia genus representatives. In all the examined representatives of Tilia genus the bloom intensity index has decreased, i.e. the number of inflorescences, number of flowers in them and the total number of flowers per branch model have dropped under conditions of industrial emissions. Moreover, the two studied species (T. cordata and T. platyphyllos) showed a reduction in the pollen grain fertility, mostly in T. cordata. The pollen size is the indicator that proved to be stable in all objects under conditions of contaminated environment. These deviations in the generative development can affect the reproductive ability of the trees.

In general, the T. europaea and T. platyphyllos species showed the highest tolerance rate of their floral organs to anthropogenic emissions. We therefore recommend them to be used as appropriate trees for gardening industrial sites in conditions of the steppe Prydniprovya, having considered their sensitivity to anthropogenic pollution in terms of other characteristics of growth and development. The floral system characteristics that significantly changed under the influence of TPP emissions, such as the bloom intensity and pollen fertility can be recommended as sensitive test parameters to monitor the environment state. T. cordata may be an informative object for these parameters.

\section{References}

[1] R.O. Striletz, Ecological passport of Dnipropetrovsk region, Dnipropetrovsk, 2014.

[2] Y.H. Smit, Forest and Atmosphere, Progress, Moscow, 1985.

[3] A.A. Kulagin, J.A. Shagieva, Woody Plants and Biological Preservation of Industrial Pollutants, Science, Moscow, 2005.

[4] M. Capuana, Heavy Metals and Woody Plants - Biotechnologies for Phytoremediation, iForest, 2011, 4, 7-15.

[5] V.P. Bessonova, Assessment of the Functional State of Woody Plants of Urbanistic Phytocenotic According to Carbohydrate Metabolism Changes. Proc. 2nd International Scientific and Pract. Conference 'Plants and urbanization', Dnipropetrovsk, 29-30 November 2011, 48-52.

[6] T.I. Iusypiva, T.S. Korostylova, Technogenic Impact on Physiological and Cytogenic Indices of Reproductive Organs of Tilia Genus Representatives. Visn. Dnipropetr. Univ. Ser. Biol. Ekol., 2015, 23(1), 10-14.

[7] L. Skärby, H. Ro-Poulsen, A.R. Wellburn, L.J. Sheppard, Impacts of Ozone on Forests: a European Perspective, New Phytol., 1998, 139, 109-122.

[8] P. Cudin, Degradation and Restoration Processes in Crowns and Fine Roots of Polluted Montane Norway Spruce Ecosystems, Phyton, 1996, 36(3), 69-76.

[9] P.R. Miller, J. McBride, Oxidant Air Pollution Impacts in The Montane Forests of Southern California: The San Bernadino Mountain Case Study, Springer-Verlag, New York, 1999.

[10] Z.V. Grytsay, T.I. Usypiva, Influence of Cokery Industry Emissions on Carbohydrates and Lipids Content of Wood Plant Leaves, Issues of Ecology and Bioindication, 2004, 9(2), 97-107.

[11] S. Gupta, D. Bhattacharjee, J.K. Datta, S. Nayek, S. Satpati, Effect of Vehicular Lead Emissions on Biochemical Constituents of Leaves, Poll. Res., 2009, 28 (2), 157-160.

[12] Z.V. Gritzay, O.G. Denisenko, Seed Production of Woody Plants in Conditions of Environment Pollution by Metallurgical Industry Emissions, Visn. Dnipropetr. Univ. Ser. Biol. Ekol., 2011, 19(2), 40-44. 
[13] O.A. Neverova, O.M. Legoshchina, A.A. Bykov, Anatomy of Lleaves of Betula pendula (Roth.) Affected by Air Emissions in Industrial Area of Kemerovo City, Middle-East Journal of Scientific Research, 2013, 17(3), 354-358.

[14] S. Petrova, L. Yurukova, I. Velcheva, Possibilities of Using Deciduous Tree Species in Trace Element Biomonitoring, Urban Area (Plovdiv, Bulgaria), Atmospheric Pollution Research, 2014, 5, 196-202.

[15] P.E. Bulah, Phenological criteria of plant sustainability and introduction, Plant Introduction, 2005, 4, $9-19$.

[16] V.M. Grishko, N.V. Mashtaler, Pollution Affect on Formation of Generative Ability of Some of Penstemon Schmidel Species Under Conditions of Mining Enterprise Industrial Site, Plant Introduction, 2009, 1, 73-79.

[17] V.P. Bessonova, T.I. Usypiva, Seed Regeneration of Woody Plants and Industrial Pollutants $\left(\mathrm{SO}_{2}\right.$ and $\left.\mathrm{NO}_{2}\right)$, Zaporizhya University Press, Zaporizhya, 2001.

[18] D. F. Karnoski, The Effects of SO2 on in vitro Forest Tree Pollen Germination and Tube Elongatson, Journal of Envir. Quality, 1974, 3, 406-409.

[19] O.A. Ponomar'ova, V.P. Bessonova, The Influence of Growth T. cordata and T. platyphyllos in Hole Into the Asphalt of Roadside Zone of Size the Morphometrix Indicators of Assimilation System, Issues of Ecology and Bioindication, 2009, 14(2), 55-62.

[20] L.S. Krupenko, N.V. Kapelush, Condition of Assimilation System Tilia cordata Under Aerogenic Pollution in Zaporozhye City, Issues of Ecology and Bioindication, 2014, 19(2), 84-90.

[21] E.A. Erofeeva, Dependence of Drooping Birch (Betula pendula) and Lime Tree (Tilia cordata) Relative Seed Production as a New Seed Production Index on the Intensity of Motor Traffic Pollution, Adv. Environ. Biol., 2014, 8(13), 282-286.

[22] Z.V. Gritzay, L.V. Shupranova, Impact of Emissions of Pridneprovsk TPP in Dnipropetrovsk on the Anatomical Indices of Stem of Two-Year Whip of the Tilia Genus Representatives, Visn. Dnipropetr. Univ. Ser. Biol. Ekol., 2015, 23(2), 230-235.

[23] Z.P. Pausheva, Practical Plant Cytology, Moscow, Agropromizdat Publ., 1988, 208-215.

[24] V. P. Bessonova, State of pollen as an indicator of pollution by heavy metals, Ecology, 1992, 4, 45-50., Ecology,1992, 4, 45 - 50.

[25] V.P. Bessonova, T.I. Usypiva, Z.V. Grytsay, Using cytogenetic criteria for assessing the mutagenicity of industrial pollutants, Cytology and Genetics, 1996, 30 (5), 70-76. (In Russian)

[26] A.I. Gorovaja, Cytogenetic evaluation of the mutagenic background in industrial Pryidniprovye, Cytology and Genetics, 1995, 6, 6-22. 